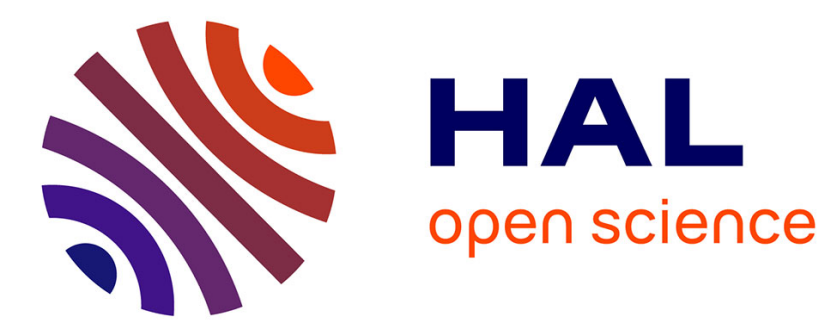

\title{
Treatment compliance with European guidelines and prognosis of Clostridium difficile infection according to age
}

\author{
M. Lauda-Maillen, E. Liuu, M. Catroux, A. Caupenne, M. Priner, F.
} Cazenave-Roblot, C. Burucoa, P. Ingrand, M. Paccalin

\section{To cite this version:}

M. Lauda-Maillen, E. Liuu, M. Catroux, A. Caupenne, M. Priner, et al.. Treatment compliance with European guidelines and prognosis of Clostridium difficile infection according to age. Médecine et Maladies Infectieuses, 2019, 49, pp.173 - 179. 10.1016/j.medmal.2018.08.001 . hal-03486827

\section{HAL Id: hal-03486827 \\ https://hal.science/hal-03486827}

Submitted on 20 Dec 2021

HAL is a multi-disciplinary open access archive for the deposit and dissemination of scientific research documents, whether they are published or not. The documents may come from teaching and research institutions in France or abroad, or from public or private research centers.
L'archive ouverte pluridisciplinaire HAL, est destinée au dépôt et à la diffusion de documents scientifiques de niveau recherche, publiés ou non, émanant des établissements d'enseignement et de recherche français ou étrangers, des laboratoires publics ou privés.

\section{다)(1) $(5$}

Distributed under a Creative Commons Attribution - NonCommerciall 4.0 International 
Treatment compliance with European guidelines and prognosis of Clostridium difficile infection according to age

Adéquation de la prise en charge thérapeutique aux recommandations européennes et pronostic des infections à Clostridium difficile selon l'âge

Lauda-Maillen $\mathrm{M}^{1}$, Liuu $\mathrm{E}^{2,5}$, Catroux $\mathrm{M}^{1}$, Caupenne $\mathrm{A}^{2}$, Priner $\mathrm{M}^{2}$, Cazenave-Roblot $\mathrm{F}^{1}$, Burucoa $\mathrm{C}^{3}$, Ingrand $\mathrm{P}^{4,5}$, Paccalin $\mathrm{M}^{2,5}$

${ }^{1}$ Service de Maladies Infectieuses, Pôle Medipool, Centre Hospitalier Universitaire de Poitiers, Poitiers, France

${ }^{2}$ Pôle de Gériatrie, Centre Hospitalier Universitaire de Poitiers, Poitiers, France

${ }^{3}$ Laboratoire de Bactériologie, Centre Hospitalier Universitaire de Poitiers, Poitiers, France ${ }^{4}$ Pôle Biologie, Pharmacie et Santé Publique, Centre Hospitalier Universitaire de Poitiers, Université de Poitiers, Poitiers, France

${ }^{5}$ INSERM, CIC 1402, Centre Hospitalier Universitaire de Poitiers, Université de Poitiers, Poitiers, France

\section{Corresponding author}

Dr M. Lauda Maillen

Service de Maladies Infectieuses ; Pôle Medipool Centre Hospitalier Universitaire de Poitiers ; 2 rue de la Milétrie BP 577 ; 86021 Poitiers. France.

Phone number: 05.49.44.44.44.

Fax: 05.49.44.40.47

Email address: maider_lauda@hotmail.com

\section{Congresses:}

JNI Lille, June 2016

SNFMI Congress, Lille, June 2016

Keywords: Clostridium difficile infection; elderly; mortality; guidelines 
Mots clés : infections à Clostridium difficile, personne âgée, mortalité, recommandations

\begin{abstract}
Objective. Age $>65$ years is associated with the recurrence and poor prognosis of Clostridium difficile infection (CDI). Data on elderly patients ( $\geq 75$ years) is scarce, and little is known about compliance with European guidelines in terms of specific treatment. We aimed to analyze the treatment and prognosis of CDI in two groups of patients aged $<$ and $\geq 75$ years.

Patients and methods. We performed a prospective survey from May 2014 to April 2015 in a university hospital including all patients presenting with microbiologically confirmed CDI. Sociodemographic and clinical data, treatment of CDI, recurrences $(<8$ weeks after CDI treatment completion), new episodes, and mortality were recorded. Follow-up was performed until February 2016.

Results. Overall, 101 patients were included; 45 were aged $\geq 75$ years (44.6\%). More than two-thirds of CDIs (71/101) were severe. Seven per cent of patients presenting with severe CDI and $10 \%$ of patients at increased risk of recurrence received the adequate treatment as per European guidelines. Mean follow-up was $15 \pm 4$ months (range: 10-22). Among patients aged $\geq 75$ years, we observed the same number of recurrences and new episodes of CDI during the follow-up. The 3-month case fatality was significantly higher in the elderly group $(P<0.001)$. The one-year survival rate was $73.2 \%$ in younger patients and $45.7 \%$ in elderly patients $(P=0.0004)$.
\end{abstract}

Conclusion. This study confirms the poor prognosis of CDI in elderly patients and highlights the lack of compliance with treatment guidelines. 


\section{Résumé}

Objectif. L’âge > 65 ans est associé à un risque de récurrence et de mauvais pronostic des infections à Clostridium difficile (ICD). Les données concernant les patients $\geq 75$ ans sont limitées et l'adéquation de la prise en charge thérapeutique des ICD aux recommandations européennes a été peu étudiée. Analyse du traitement et du pronostic des ICD en comparant deux groupes de patients âgés de $<$ et $\geq 75$ ans (mai 2014-avril 2015).

Patients et méthodes. Nous avons inclus tous les cas d'ICD confirmés microbiologiquement. Les données sociodémographiques et cliniques, le traitement, les récurrences ( $<8$ semaines après la fin du traitement), les nouveaux épisodes et la mortalité ont été recueillis. La cohorte a été suivie jusqu'en février 2016.

Résultats. 101 patients ont été inclus ; 45 âgés de $\geq 75$ ans (44,6 \%). 71/101 patients étaient graves, $7 \%$ des patients ayant une ICD grave et $10 \%$ des patients ayant un risque élevé de récurrence ont reçu un traitement adapté selon les recommandations européennes. Avec une limite à 75 ans, le nombre de récurrences et d’épisodes ultérieurs d'ICD était identique dans les deux groupes. Le taux de mortalité à 3 mois était plus élevé chez les patients très âgés $(P<0,001)$. Le taux de survie à un an était de 73,2 \% chez les patients $<75$ ans et de 45,7\% chez ceux $\geq 75$ ans $(P=0,0004)$.

Conclusion. Cette étude souligne le mauvais pronostic des ICD chez les personnes âgées et la faible adéquation aux recommandations thérapeutiques. 


\section{Introduction}

Clostridium difficile (CD) is considered the first cause of nosocomial diarrhea. The incidence of CD infection (CDI) has increased in France to reach 3.6 cases per 10,000 patient-days in 2012, with an annual attributable cost of around 160 million euros [1-3]. The morbidity rate and case fatality of this infection are high, with a 30\% risk of recurrence [4] and a 3-month case fatality of $20 \%$ [5]. European guidelines were published in 2014, but little is known about the compliance with these recommendations [6]. Older age is usually associated with poor prognosis in terms of severity, recurrence, and mortality [7-9]. Yet the age to consider risks of severe CDI and of recurrence in the literature is low, with a cut-off at the age of 65 . Data focusing on patients aged over 75 years is scarce.

The aim of our study was to analyze the treatment and long-term prognosis of CDI in two groups of patients aged $<$ and $\geq 75$ years.

\section{Methods}

We performed a one-year prospective survey, from May 2014 to April 2015, in a university hospital (1,698 beds) with a geriatric department (490 beds: acute care, rehabilitation, long-term care). All cases of CD isolated from stool samples in our microbiology laboratory led to investigations in the clinical units, and only patients with a confirmed diagnosis of CDI were included. Cases were defined as described in the European guidelines [6]: a clinical picture compatible with CDI (diarrhea, ileus, or toxic megacolon) and microbiological evidence of free toxins and presence of $C$. difficile in unformed stool without reasonable evidence of another cause of diarrhea; or pseudomembranous colitis. A two-step algorithm is used at our hospital to detect CD: first with a glutamate dehydrogenase (GDH) test (C. DIFF QUIK CHEK ${ }^{\circledR}$ ) [10] and positive GDH stool samples are then tested by 
real-time polymerase chain reaction (Xpert ${ }^{\circledR}$ C. difficile on Cepheid GeneXpert ${ }^{\circledR}$ Dx System) assay to detect the presence of $t c d B$, binary toxin genes (cdt), and deletion nt 117 on tcdC gene characteristic of the BI/NAP1/O27 strain. A positive GDH and PCR sample is considered a positive microbiological test.

\section{Data collection}

A standardized questionnaire was filled in at baseline: demographic data and immunocompromised status (malignancy, chemotherapy or immunosuppressive treatment, corticosteroid therapy) were collected. The following risk factors associated with CDI were recorded: antibiotic exposure before and during the hospital stay, proton pump inhibitor therapy and number of hospitalizations in the previous year. Antibiotic exposure three months before hospitalization was recorded based on the patients' history and phone calls to family physicians. Duration of symptoms and specific treatment for CDI were recorded. As our hospital did not have any policy for CDI antibiotic administration, physicians were free to prescribe the treatment of their choice for CDI. Markers to determine severe CDI and increased risk of recurrence were collected, as per European guidelines [6]. Thus, fever $>38.5^{\circ} \mathrm{C}$, albuminemia $<30 \mathrm{~g} / \mathrm{L}$, leucocyte count $>15.10^{9} / \mathrm{L}$, rise in serum creatinine level ( $\geq 133 \mu \mathrm{mol}$ or $\geq 1.5$ times the premorbid level), and colitis (colonic ileus, peritonitis, CT scan complications, pseudomembranous colitis) were used to determine severe CDI. Age >65 years, history of previous CDI, antibiotic continuation after diagnosis of CDI, concomitant use of proton pump inhibitors, initial disease severity, and renal failure were used to determine an increased risk of recurrence. CDI was defined as community-acquired when occurring before hospital admission or within three days after admission without any overnight stay in a healthcare facility in the previous 12 weeks. Specific treatment, 
compliance with treatments recommended in the European guidelines, and new episodes of CDI (recurrences within eight weeks after resolution of the initial episode and other episodes occurring more than eight weeks after resolution of the initial episode) were recorded. Follow-up and case fatality were assessed using a standardized process until February 2016 by calling family physicians and reviewing medical records on the same day. The protocol was approved by the local ethics committee.

\section{Statistical analysis}

Qualitative variables were compared by Fisher's exact test and quantitative variables by the Mann-Whitney test with the SAS system package. The survival analysis used the KaplanMeier method and logrank test. Statistical significance was considered if a 2-sided $P$ value was $\leq 0.05$.

\section{Results}

A total of 1,525 stool samples were tested for CD during the 12-month enrolment period, of which 173 were positive by GDH test and 131 by PCR. No BI/NAP1/O27 strain was isolated. After clinical investigation, 101 patients with CDI diagnosis were included with a mean age of $68.1 \pm 19.2$ years and 45 patients aged $\geq 75$ years (44.6\%) (Figure 1 ). As $10.2 \%$ were diagnosed as community-acquired, the nosocomial incidence of CDI was estimated at 8.1 cases per 100,000 patient-days (95\% CI: 6.6-9.9).

Elderly patients commonly lived in nursing homes (37.8\%). Younger patients were significantly more immunosuppressed $(P=0.028)$ according to our criteria, with more hospital stays in the previous year $(P=0.006)$. The main causes of immunosuppression were neoplasia 
( $\mathrm{n}=38,27$ patients <75 years), chemotherapy ( $\mathrm{n}=23,19<75$ years), and prolonged corticosteroid therapy ( $\mathrm{n}=15,12<75$ years) (Table I).

The two groups of patients were similar in terms of risk factor exposure. One-third had received antibiotics within three months before admission and nearly half of patients were treated with antibiotics at the time of CDI diagnosis, mainly penicillins and cephalosporins. Over two-thirds of CDIs (71/101) were considered severe (Table II). The mean numbers of markers determining a severe CDI and determining an increased risk of recurrence were similar, irrespective of age. Nevertheless, fever $>38.5^{\circ} \mathrm{C}$ was more frequent in the younger group ( $P=0.042$ ), whereas albuminemia $<30 \mathrm{~g} / \mathrm{L}$ was more frequent in patients aged $\geq 75$ years $(P=0.041)$. Among the 30 patients presenting with non-severe CDI, 28 presented with at least one risk factor for recurrence. Metronidazole was the first-line antibiotic prescribed to $87.3 \%$ of severe CDI patients and to $90 \%$ of non-severe CDI patients. First-line treatment failure was reported in 18 patients (17.8\%). Second-line treatment included oral vancomycin in 13 patients, oral vancomycin combined with intravenous metronidazole in one patient, and fidaxomicin in one patient. A third-line treatment was prescribed to three patients: fidaxomicin $(n=2)$ and oral vancomycin combined with parenteral metronidazole $(n=1)$.

Mean duration of first-line treatment was 9.5 \pm 3.2 days (similar in both groups). Mean duration of overall specific treatment was $11.6 \pm 7.7$ days in group 1 and $11.2 \pm 4.5$ days in group 2.

According to the European guidelines, $7 \%$ and $10 \%$ of patients respectively presenting with severe CDI and risk of recurrence received the adequate treatment regimen. The percentage of adequate treatments was higher in non-severe CDI cases (60\%; 18/30).

\section{Prognosis}

The median duration of hospital stay was 21 days [0-158 days], similar in both groups. One 
patient died before initiating the specific antibiotic treatment. Three patients died while treated with the first-line antibiotic. Fifteen recurrences were recorded during follow-up (seven in group 1) and were treated as per European guidelines in nine cases (60\%). Seven

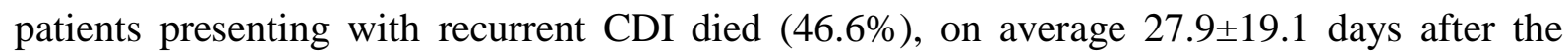
diagnosis of recurrence. Median follow-up of the cohort was 15 months (range 10-22). Another episode of CDI (>8 weeks after resolution of the initial episode) occurred in seven patients: six patients $<75$ years and $1 \geq 75$ years, respectively $6.3 \pm 4.6$ months and 9 months after the initial diagnosis. Overall, 22 patients relapsed after the first episode of CDI, 13 patients $<75$ years $(23.2 \%)$ and nine $\geq 75$ years $(20 \%)$. The case fatality was $23.8 \%$ during the hospital stay and $32.7 \%$ after three months of follow-up, significantly higher in elderly patients (Table III). Ten additional deaths were recorded after the third month, with a mean time of $8.7 \pm 5.3$ months after the initial CDI diagnosis: six deaths $(12.8 \%)$ in patients $<75$ years and four (19\%) in patients $\geq 75$ years. Median survival after CDI diagnosis was 3.3 months in patients $\geq 75$ years. The one-year survival rate was $74 \pm 6 \%$ in the younger patient group and $36.4 \pm 7.7 \%$ in the elderly group $(P=0.0004)$ (Figure 2$)$.

\section{Discussion}

Clostridium difficile infection is associated with significant morbidity and mortality. As data on CDI in elderly patients is scarce, we aimed to compare the management and prognosis of this disease in two groups of patients aged $<75$ and $\geq 75$ years. In this survey, CDI incidence was $0.81 / 10,000$ patients-day, i.e. lower than the French CDI incidence reported at 3.6 \pm 2.9 cases per 10,000 patient-days [2]. Metronidazole was the most often used antibiotic with a low compliance with European guidelines. The three-month survival rate was $67.3 \%$, higher than the rates reported in previous studies $[5,11]$ and particularly unfavorable in elderly 
patients. The one-year survival rate was also significantly lower in this same group $(P=0.0004)$. In our study the number of markers determining severe CDI and increased risk of recurrence was the same in both groups. The cut-off age of 75 and the higher number of patients with criteria for immunodeficiency might explain this result differing from those of previous studies [3, 5, 6, 9, 10, 12-17]. It should also be noted that we did not collect any data on comorbidities such as heart failure, diabetes, or cognitive disorder that would probably be more frequent in patients aged $\geq 75$ years. Age and immunosenescence are known to enhance the risk and the poor prognosis of CDI. In elderly people, structural changes occur in the ecosystem with decline of protective bacterial species and increase of detrimental ones, leading to the alteration of the microbiotas [18]. Antibiotics are well-known risk factor for CDI; they disrupt the natural protective microbiota enabling the overgrowth of Clostridium difficile and toxin expression. Advanced age is associated with higher antibiotic exposure and prolonged hospitalization. Immunodeficiency also contributes to the pathogenesis of CDI. Immunocompromised and cancer patients are often exposed to hospital environment, antibiotics, and gastric acid-suppressing medications. Chemotherapeutic agents alter the commensal flora and have an antimicrobial-like effect on the microbiota similar to antibiotics [19]. Gastric acid-suppressing medications, such as proton pump inhibitors prescribed to 54\% of the cohort, alter the protective effect of gastric acid and increase the load of bacterial species leading to decreasing bacterial diversity and disrupting the gut microbiota [20]. Glucocorticoids, due to their anti-inflammatory and immunosuppressive effects, also increase the risk of CDI, all the more if patients received this treatment at the time of CDI [21]. Our study underlines the lack of knowledge or of consideration of guidelines. This lack of compliance with European guidelines needs to be highlighted as metronidazole was prescribed regardless of the severity or the risk of recurrence, while vancomycin or fidaxomicin are recommended. It is difficult to say if this non-compliance is associated with 
the high case fatality, as literature data is heterogeneous [8, 22, 23]. Nevertheless, guidelinecompliant therapy was associated with a significant reduction in recurrence and mortality on Day 30 [24]. The frequency of recurrences was $14.8 \%$, close to literature data reporting figures between $18 \%$ and $25 \%$ [ $4,5,16,25,26]$. However, the recurrence rate is identical in both groups, which is not consistent with previous literature data $[4,16,25,26]$. The low sample size of our study, the cut-off age of 75 , and the high rate of young immunocompromised patients may again explain this result. If we had chosen a cut-off age of 65, 11 patients $\geq 65$ years would have developed recurrent CDI (within eight weeks after resolution of the initial episode), almost three times the number of recurrences $(n=4)$ in patients $<65$ years. The association between age and poor prognosis is well known [6, 27, 28]. A recent review focusing on the 30-day case fatality reported an increased rate in patients aged $>70$ years [26]. CDI is associated with an almost twice higher mortality in adults aged $>65$ years $(P<0.001)$ [12]. The median survival of patients aged $\geq 75$ years in our cohort $(3.3$ months) is close to the result of a retrospective study also evaluating CDI in elderly patients (mean age $86 \pm 4.8$ ) [8]. A higher case fatality observed among elderly patients is not surprising. Although we did not collect the number of comorbidities, this group of patients was significantly more often institutionalized, which means that most of them were probably affected by multiple comorbidities. However, this higher case fatality cannot be attributable to CDI recurrences. A recent study reported a decreased case fatality attributable to CDI particularly in elderly patients, due to the reduced transmission of virulent strains thanks to infection control measures and improved testing allowing for an earlier treatment [29]. The lack of compliance with guidelines could be explained by the lack of local policy to treat CDI. Although all patients were symptomatic, thus reducing the risk of including colonized patients and although we used a high cut-off for age, our study has several limitations. It was a monocenter study with a low sample size. Results thus cannot be generalized to the overall 
population. We did not collect any score of comorbidities, which could have influenced the prognosis. The causes of death were not recorded, and we were not able to determine how many deaths were attributable to CDI.

\section{Conclusion}

The occurrence of CDI and severe CDI was as often described in patients aged $<75$ years as in patients aged $\geq 75$ years, and the number of recurrences was not different. As expected, the case fatality was significantly higher in elderly patients. Our study highlights the lack of compliance with treatment guidelines. 


\section{Contributions of author}

Dr M. Lauda-Maillen designed the study protocol, collected the data, analyzed the data, and wrote the article.

Dr E. Liuu analyzed the data and reviewed the article.

Dr M. Catroux analyzed the data and reviewed the article.

Dr A. Caupenne designed the study protocol, analyzed the data, and reviewed the article.

Dr M. Priner designed the study protocol, analyzed the data, and wrote the article.

Pr F. Cazenave-Roblot analyzed the data and reviewed the article.

Pr C. Burucoa analyzed the data and reviewed the article.

Pr P. Ingrand analyzed the data, performed the statistical analysis, and reviewed the article.

Pr M. Paccalin designed the study protocol, analyzed the data, and wrote the article. 


\section{References}

1. Le Monnier A, Duburcq A, Zahar JR, Corvec S, Guillard T, Cattoir V, et al. Hospital cost of Clostridium difficile infection including the contribution of recurrences in French acute-care hospitals. J Hospit Infect. 2015;91:117-22.

2. Barbut F, Rame L, Petit A, Suzon L, de Chevigny A, Eckert C. Prevalence of Clostridium difficile infection in hospitalized patients with diarrhea: results of a French prospective multicenter bi-annual point prevalence study. Presse Med. 2015;44:e75-83.

3. Davies KA, Longshaw CM, Davis GL, Bouza E, Barbut F, Barna Z, et al. Underdiagnosis of Clostridium difficile across Europe: the European, multicentre, prospective, biannual, point-prevalence study of Clostridium difficile infection in hospitalised patients with diarrhoea (EUCLID). Lancet Infect Dis. 2014;14:1208-19.

4. Kelly CP. Can we identify patients at high risk of recurrent Clostridium difficile infection? Clin Microbiol Infect. 2012;18 Suppl 6:21-7.

5. Bauer MP, Notermans DW, van Benthem BH, Brazier JS, Wilcox MH, Rupnik M, et al. Clostridium difficile infection in Europe: a hospital-based survey. Lancet. 2011;377:63-73.

6. Debast SB, Bauer MP, Kuijper EJ. European Society of Clinical Microbiology and Infectious Diseases: update of the treatment guidance document for Clostridium difficile infection. Clin Microbiol Infect. 2014;20 Suppl 2:1-26.

7. Abou Chakra CN, McGeer A, Labbe AC, Simor AE, Gold WL, Muller MP, et al. Factors Associated With Complications of Clostridium difficile Infection in a Multicenter Prospective Cohort. Clin Infect Dis. 2015;61:1781-8.

8. Leibovici-Weissman Y, Atamna A, Schlesinger A, Eliakim-Raz N, Bishara J, Yahav

D. Risk factors for short- and long-term mortality in very old patients with Clostridium difficile infection: A retrospective study. Gerontol Geriatr Int. 2016.ahead of print

9. Larrainzar-Coghen T, Rodriguez-Pardo D, Puig-Asensio M, Rodriguez V, Ferrer C, Bartolome R, et al. First recurrence of Clostridium difficile infection: clinical relevance, risk factors, and prognosis. Eur J Clin Microbiol Infect. 2016;35:371-8.

10. Crobach MJ, Planche T, Eckert C, Barbut F, Terveer EM, Dekkers OM, et al. European Society of Clinical Microbiology and Infectious Diseases: update of the diagnostic guidance document for Clostridium difficile infection. Clin Microbiol Infect. 2016;22 Suppl 4:S63-81. 
11. Hensgens MP, Goorhuis A, Dekkers OM, van Benthem BH, Kuijper EJ. All-cause and disease-specific mortality in hospitalized patients with Clostridium difficile infection: a multicenter cohort study. Clin Infect Dis. 2013;56:1108-16.

12. Shorr AF, Zilberberg MD, Wang L, Baser O, Yu H. Mortality and Costs in Clostridium difficile Infection Among the Elderly in the United States. Infect Control Hosp Epidemiol. 2016;37:1331-6.

13. Cornely OA, Crook DW, Esposito R, Poirier A, Somero MS, Weiss K, et al. Fidaxomicin versus vancomycin for infection with Clostridium difficile in Europe, Canada, and the USA: a double-blind, non-inferiority, randomised controlled trial. Lancet Infect Dis. 2012;12:281-9.

14. Louie TJ, Miller MA, Mullane KM, Weiss K, Lentnek A, Golan Y, et al. Fidaxomicin versus vancomycin for Clostridium difficile infection. N Engl J Med. 2011;364:422-31.

15. Olsen MA, Yan Y, Reske KA, Zilberberg MD, Dubberke ER. Recurrent Clostridium difficile infection is associated with increased mortality. Clin Microbiol Infect. 2015;21:16470.

16. Eyre DW, Walker AS, Wyllie D, Dingle KE, Griffiths D, Finney J, et al. Predictors of first recurrence of Clostridium difficile infection: implications for initial management. Clin Infect Dis. 2012;55 Suppl 2:S77-87.

17. Leffler DA, Lamont JT. Clostridium difficile infection. N Engl J Med. 2015;372:153948.

18. Hopkins MJ, Macfarlane GT. Changes in predominant bacterial populations in human faeces with age and with Clostridium difficile infection. J Med Microbiol. 2002;51:448-54.

19. Collini PJ, Bauer M, Kuijper E, Dockrell DH. Clostridium difficile infection in HIVseropositive individuals and transplant recipients. J Infect. 2012;64:131-47.

20. Tariq R, Singh S, Gupta A, Pardi DS, Khanna S. Association of Gastric Acid Suppression With Recurrent Clostridium difficile Infection: A Systematic Review and Metaanalysis. JAMA Intern Med. 2017 1;177:784-791.

21. Das R, Feuerstadt P, Brandt LJ. Glucocorticoids are associated with increased risk of short-term mortality in hospitalized patients with Clostridium difficile-associated disease. Am J Gastroenterol. 2010;105:2040-9.

22. Pham VP, Luce AM, Ruppelt SC, Wei W, Aitken SL, Musick WL, et al. AgeStratified Treatment Response Rates in Hospitalized Patients with Clostridium difficile Infection Treated with Metronidazole. Antimicrob Agents Chemother. 2015;59:6113-6. 
23. Bagdasarian N, Rao K, Malani PN. Diagnosis and treatment of Clostridium difficile in adults: a systematic review. JAMA. 2015;313:398-408.

24. Brown AT, Seifert CF. Effect of treatment variation on outcomes in patients with Clostridium difficile. Am J Med. 2014;127:865-70.

25. Sheitoyan-Pesant C, Abou Chakra CN, Pepin J, Marcil-Heguy A, Nault V, Valiquette

L. Clinical and Healthcare Burden of Multiple Recurrences of Clostridium difficile Infection. Clin Infect Dis. 2016;62:574-80.

26. Abou Chakra CN, Pepin J, Sirard S, Valiquette L. Risk factors for recurrence, complications and mortality in Clostridium difficile infection: a systematic review. PloS one. 2014;9:e98400.

27. Abou Chakra CN, Pepin J, Valiquette L. Prediction tools for unfavourable outcomes in Clostridium difficile infection: a systematic review. PloS one. 2012;7:e30258.

28. Henrich TJ, Krakower D, Bitton A, Yokoe DS. Clinical risk factors for severe Clostridium difficile-associated disease. Emerg Infect Dis. 2009;15:415-22.

29. Shrestha MP, Bime C, Taleban S. Decreasing Clostridium difficile-associate fatality rates among hospitalized patients in the United Staes: 2004-2014. Am J Med. 2017 in press

Figure 1. Flow chart

Figure 1. Diagramme de flux 


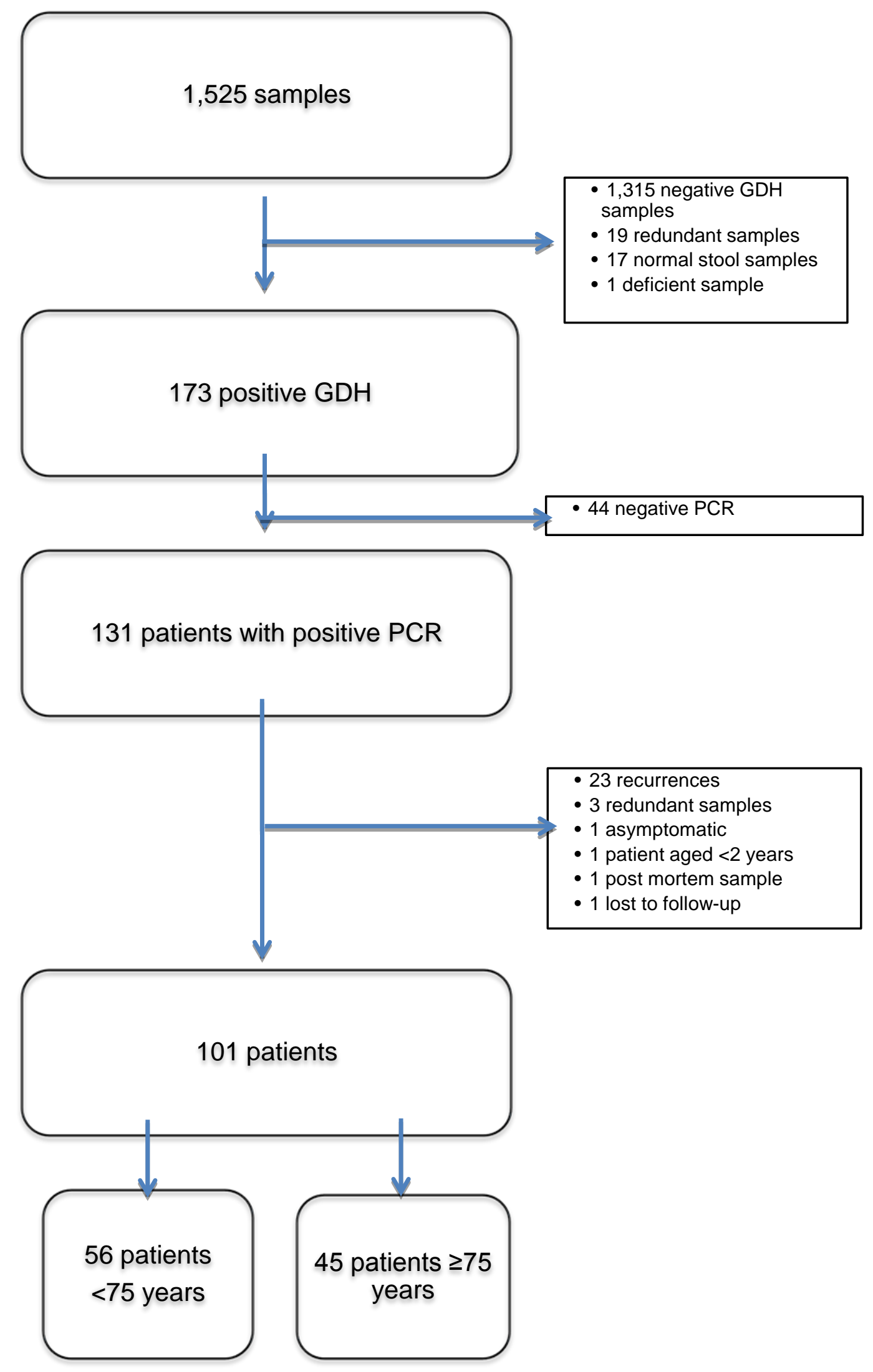

Figure 2. Kaplan-Meier survival estimates

Figure 2. Courbes de survie de Kaplan-Meier 


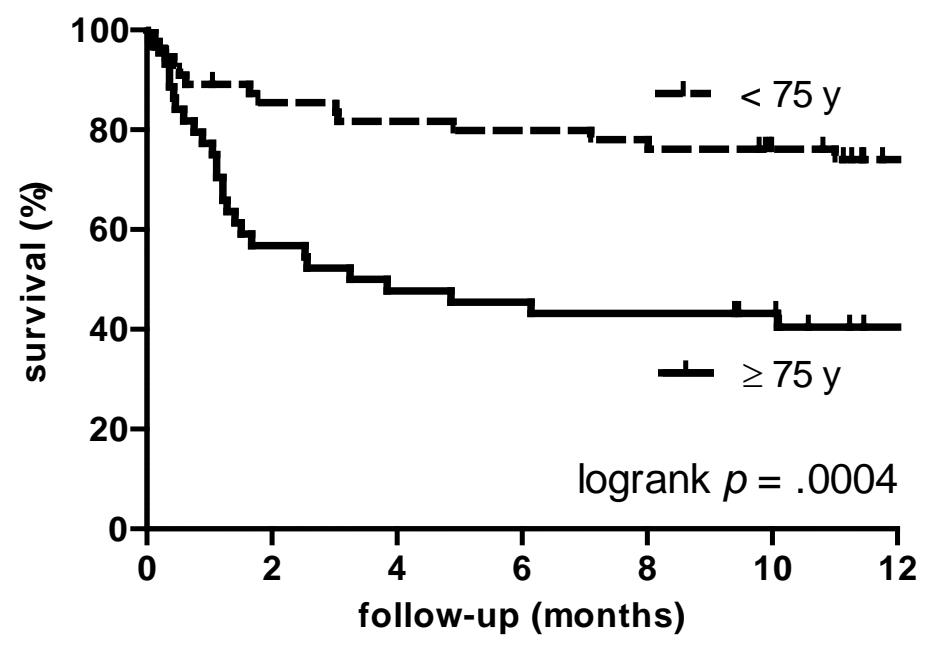

Table I. Characteristics of patients and exposure to risk factors

Tableau I. Caractéristiques des patients et exposition aux facteurs de risque

$$
<75 \text { years } \quad \geq 75 \text { years }
$$

\begin{tabular}{|lccc|}
\hline $\mathbf{n}$ & 56 & 45 & $P$ \\
\hline Age (years) & $55.5 \pm 2.2$ & $83.8 \pm 1.0$ & \\
\hline Men (\%) & $34(60.7)$ & $14(31.1)$ & $\mathbf{. 0 0 4 8}$ \\
\hline Living at home (\%) & $52(92.9)$ & $28(62.2)$ & $\mathbf{. 0 0 0 2}$ \\
\hline Living in nursing homes (\%) & $4(7.1)$ & $16(36.4)$ & .0004 \\
\hline Community-acquired CDI (\%) & $4(7.1)$ & $6(13.3)$ & .33 \\
\hline $\begin{array}{l}\text { Median duration (days) of hospital } \\
\text { stay before symptom onset }\end{array}$ & $6(0-13)$ & $5(0-15)$ & .91 \\
\hline $\begin{array}{l}\text { Antibiotic exposure 3 months before } \\
\text { hospitalization (\%) }\end{array}$ & $34(60.7)$ & $32(71.1)$ & .30 \\
\hline $\begin{array}{l}\text { Antibiotic exposure in hospital (\%) } \\
\text { Antibiotics at the time of symptoms }\end{array}$ & $42(75.0)$ & $32(72.7)$ & .82 \\
(\%) & $30(53.6)$ & $22(48.9)$ & .69 \\
\hline
\end{tabular}




\begin{tabular}{|c|c|c|c|}
\hline $\begin{array}{l}\text { Continued use of antibiotics after } \\
\text { diagnosis of CDI (\%) }\end{array}$ & $27(48.2)$ & $20(44.4)$ & .84 \\
\hline Immunosuppression (\%) & $35(62.5)$ & $18(40.0)$ & .029 \\
\hline $\begin{array}{l}\text { Concomitant use of proton pump } \\
\text { inhibitor (\%) }\end{array}$ & $29(51.8)$ & $26(57.8)$ & .69 \\
\hline Number of medications & $7.45 \pm 4.99$ & $7.93 \pm 2.95$ & .48 \\
\hline $\begin{array}{l}\text { Number of hospital stays in the last } \\
\text { year }\end{array}$ & $2.18 \pm 2.22$ & $1.09 \pm 1.53$ & .004 \\
\hline $\begin{array}{l}\text { Median time (days) since the last } \\
\text { hospital stay }\end{array}$ & $28(10-103)$ & $17(9-69)$ & .54 \\
\hline \multicolumn{4}{|c|}{$\begin{array}{l}\text { Continuous variables were expressed as mean } \pm \text { SD or median (interquartile range: } 25 \\
\text { CDI: Clostridium difficile infection. } \\
\text { Table II. Criteria for severe Clostridium difficile infection (CDI) according to the Eur } \\
\text { guidelines [6] } \\
\text { Tableau II. Critères de sévérité des infections à Clostridium difficile (ICD) selon les } \\
\text { recommandations européennes }\end{array}$} \\
\hline & $\begin{array}{c}<75 \text { years } \\
n=56\end{array}$ & $\begin{array}{c}\geq 75 \text { years } \\
n=45\end{array}$ & $P$ \\
\hline Severe CDI (\%) & $40(71.5)$ & $31(68.9)$ & .83 \\
\hline Number of prognostic markers of severity & $1.36 \pm 1.23$ & $1.53 \pm 1.41$ & .58 \\
\hline $\begin{array}{l}\text { Decreased blood albumin <30 g/l (61 } \\
\text { samples) }\end{array}$ & $11(36.7)$ & $20(64.5)$ & .041 \\
\hline Leucocyte count $>15 \times 10^{9} / \mathrm{L}$ & $17(30.4)$ & $17(37.8)$ & .53 \\
\hline $\begin{array}{l}\text { Rise in serum creatinine level }(>133 \mu \mathrm{M} / \mathrm{l} \text { or } \\
>50 \% \text { above the baseline) }\end{array}$ & $13(23.2)$ & $14(31.1)$ & .50 \\
\hline Fever $>38.5^{\circ} \mathrm{C}$ & $28(50.0)$ & $13(28.9)$ & .042 \\
\hline Colonic ileus & 2 & 1 & - \\
\hline Peritonitis & 0 & 0 & - \\
\hline CT scan complications (22 imaging tests) & 7 & 3 & - \\
\hline Pseudomembranous colitis (6 colonoscopies) & 0 & 1 & - \\
\hline
\end{tabular}


Continuous variables were expressed as mean ( \pm SD)

CDI: Clostridium difficile infection 
Table III. Follow-up of patients

Tableau III. Suivi des patients

\begin{tabular}{lccc}
\hline & $\begin{array}{c}<75 \text { years } \\
\mathbf{n = 5 6}\end{array}$ & $\begin{array}{c}\geq \mathbf{7 5} \text { years } \\
\mathbf{n = 4 5}\end{array}$ & $\boldsymbol{P}$ \\
\hline Length of hospital stay (days) & $21(9-34)$ & $22(15-40)$ & .40 \\
Number of recurrences (<8 weeks) (\%) & $7(12.5)$ & $8(17.8)$ & .58 \\
Hospital case fatality (\%) & $8(14.3)$ & $16(35.6)$ & .018 \\
Three-month case fatality (\%) & $9(16.1)$ & $24(53.3)$ & $<.0001$ \\
New CDI episodes (\%) & $13(23.2)$ & $9(20)$ & .68 \\
\hline
\end{tabular}

CDI: Clostridium difficile infection

New CDI episode: all episodes occurring during the follow-up after the initial CDI, episode within eight weeks after resolution of the initial episode (recurrence), and other episodes occurring more than eight weeks after resolution of the initial episode. 